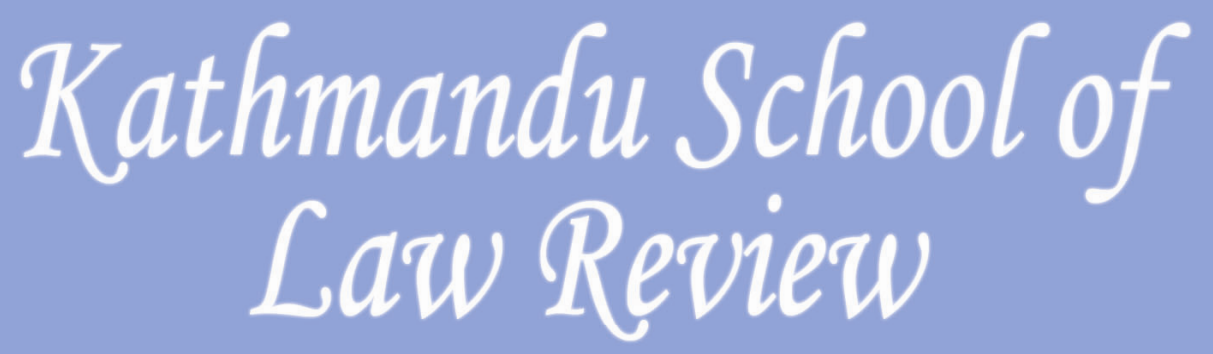

ISSN 2091-2110

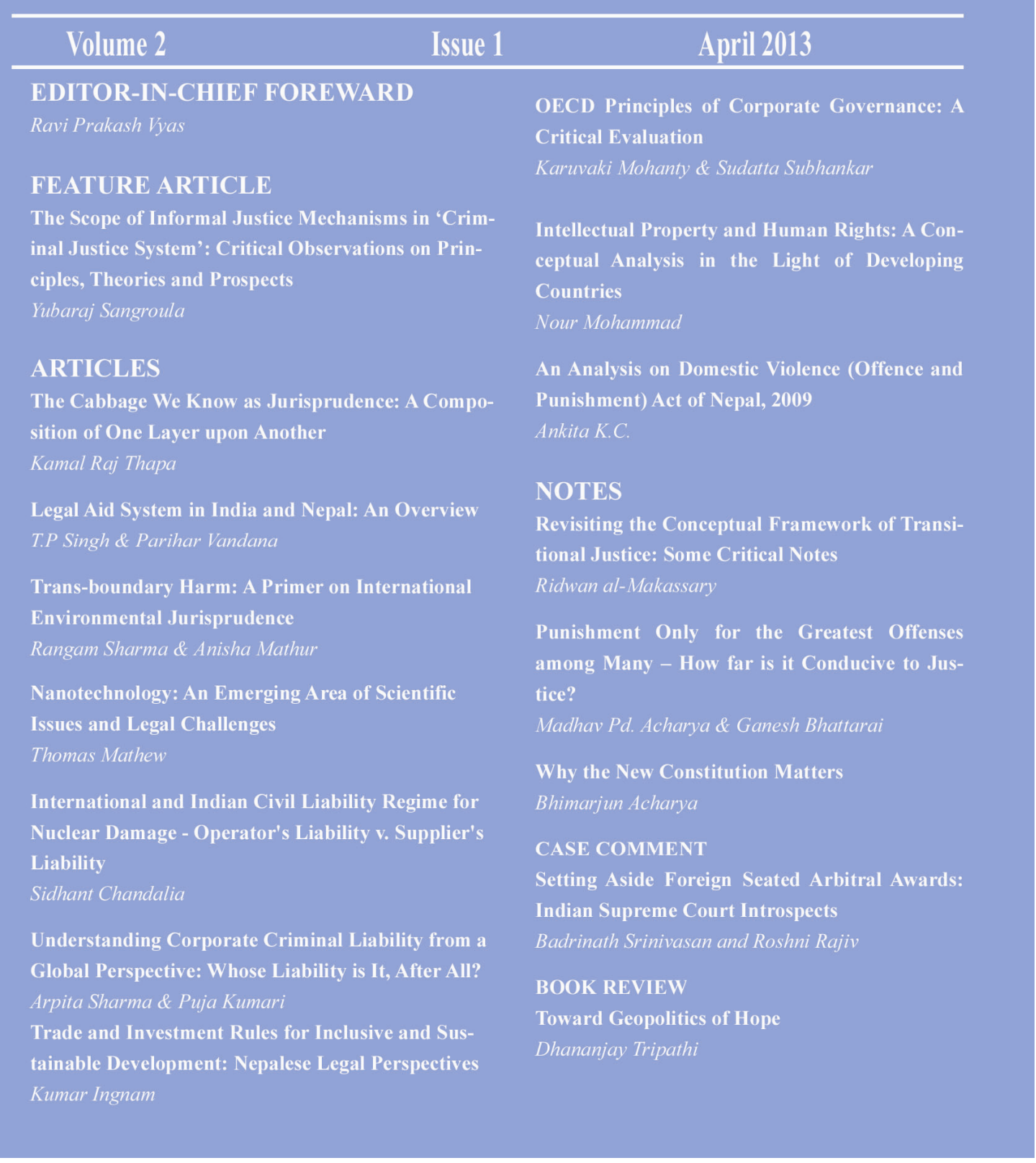




\title{
An Analysis on Domestic Violence (Offence and Punishment) Act of Nepal, 2009
}

\begin{abstract}
Women have always been an object of gross and severe violence at the hands of man. The biological weakness of a woman makes her an easy prey to all and sundry. She often is a victim of physical and mental violence not only outside her home but also inside it. Every society accepting the importance of equality of sexes has therefore, made affirmative provisions against gender discrimination. However, in spite of the enactment of these kinds of provisions, equality between men and women continues to be an elusive goal. Hence, women are deprived of basic freedom and thereby are easily exposed to exploitation. This has led violence against women to be a global phenomenon. Violence against women has been gradually recognized to be an important aspect of human rights violation of women. The author this article tries to highlight the concept of violence against women, analyzing the legislative tools available dealing with the violence against women. The author compares the domestic laws dealing on the violence against women with the international tools and draws the attention on the lacunas of domestic laws. The author also recommends what need to be done in future to address the aspect of violence against women in an effective way.
\end{abstract}

Ankita KC ${ }^{1}$

\section{Conceptual Framework}

Violence against women is a manifestation of historically unequal power relations between men and women, which have led to domination over and discrimination against women by men which is detrimental to the full advancement of women. Twenty years ago, violence against women was not considered an issue worthy of international attention or concern. Victims of violence suffered in silence, with little public recognition of their plight. This began to change in the 1980s as women's groups assembled locally and internationally to demand attention to the physical, psychological, and economic abuse of women. Gradually, violence against women came to be recognized as a legitimate human rights issue and a

Student at Kathmandu School of Law, Nepal 
significant threat to women's health and well-being. For over three decades, women's advocacy groups around the world have been working to draw more attention to the physical, psychological, and sexual abuse of women and to stimulate action. Being the member of United Nation Convention on Elimination of all forms of Discrimination against Women (hereinafter CEDAW), States Parties have condemned discrimination against women in all its forms. Domestic Violence is one of complex forms of violence against women. ${ }^{2}$

Of all the violence against women, domestic violence is most serious type because it is caused silently within the four walls of a home. It is a global phenomenon and has been on the rise constantly spreading its tentacles far and wide. ${ }^{3}$ Even the legal systems and the scholars in the name of protection, has discriminated women which ultimately is resulting in violence. Ann C. Scales views that 'maleness is the norm of what is human'. ${ }^{4}$ Similarly Supreme Court of New Brunswick said that women do not fall under the definition of person hence denied women to hold the license of attorney. ${ }^{5}$ U.S Supreme Court also viewed that 'man is, or should be, women's protector and defender. The natural and proper timidity and delicacy which belongs to the female sex and eventually unfits it for many of the occupation of civil life. ${ }^{6}$ Contstance Frisby Fain mentions 'extensive research has revealed that the practice of wife abuse permits all racial, cultural, educational, and economic classes, and occurs in both urban and rural communities'. ${ }^{7}$

After having research on various communities, R. Emerson Dobash and Russel P.Dobash have concluded that: ${ }^{8}$

[I]t has only been a hundred years since men were denied the legal right to beat their wives in Britain and the United States. Prior to the late $19^{\text {th }}$ Century it was considered a necessary aspect of a husband's, marital obligation to control and chastise his wife through the use of physical force. The legal prescriptions which once supported this practice no longer exist yet the behavior continues unabated. Behavior which was once legally condoned is now prohibited by law, yet cultural and normative prescriptions still support such practice and it is only mildly condemned, if at all, by law enforcement and judicial institutions.

2 Navneet Kumar Misra \& Neha Bakshi, 'Unite to End Violence Against Women'

$<$ http://www.slideshare.net/helloindia05/violence-against-women-research-paper> accessed 4 November 2012.

3 'Dowry System in India' <http://www.speakingtree.in/spiritual-blogs/seekers/faith-and-rituals/dowrysystem-in-indian-society\&sort=new> accessed 28 April 2013.

$4 \quad$ M.D.A., Freeman Lloyd's Introduction to Jurisprudence, $\left(6^{\text {th }}\right.$ edn, Sweet \& Maxwell 1994) 1029.

$5 \quad$ Catherine A. Makinnon, Sex Equality (Foundation Press 2001) 155.

$6 \quad$ Bradwell v State 83 US 16130 (1872).

7 Cosntannce Frsiby Fain, 'Conjugal Violence: Legal and Pyscho Sociological Remedies' (1981) Syracuse Law 497.

$8 \quad$ Catherine A. Mackinnon, Sex Equality (Foundation Press 2001) 724. 
The term 'domestic violence' consists of two words: domestic and violence. Domestic generally denotes or pertains to the home, the household, household affairs, or the family. This word was evolved from Latin word domesticus which is derived from 'domus' that translates into house. Likewise, violence refers to rough or injurious physical force, action, or treatment; an unjust or unwarranted exertion of force or power, as against rights or laws 9 . Hence, the terminological meaning of domestic violence is injurious physical force within the house.

According to Black's Law Dictionary, domestic violence means violence between member of a household, usually spouses; an assault or other violent act committed by one member of household against another ${ }^{10}$. This definition has left the ground that domestic violence can happen either against female or male by either of them. Victim and offender can reside either in the same house / premise or in geographical distance but pre-condition is that they should have familial relationship.

Domestic violence includes violence perpetrated by intimate partners and other family members, and manifested through: ${ }^{11}$

- Physical abuse such as slapping, beating, arm twisting, stabbing, strangling, burning, choking, kicking, threatening with an object or weapon, and murder. It also includes traditional practices harmful to women such as female genital mutilation and wife inheritance (the practice of passing a widow and her property, to her dead husband's brother).

- Sexual abuse such as coerced sex through threats, intimidation or physical force, forcing unwanted sexual acts or forcing sex with others.

- Psychological abuse which includes behavior that is intended to intimidate and persecute, and takes the form of threats of abandonment or abuse, confinement to the home, surveillance, threats to take away custody of the children, destruction of objects, isolation, verbal aggression and constant humiliation.

- Economic abuse includes acts such as the denial of funds, refusal to contribute financially, denial of food and basic needs, and controlling access to health care, employment etc.

Nepal adopted Domestic Violence (Offence and Punishment) Act on 2009 for the control of domestic violence and the legislations is comparatively modern. This Act basically encompasses maximum aspects of domestic violence in its definition. Section 2 of Domestic Violence (Offence and Punishment) Act 2009, defines domestic violence act as 'any form of physical, mental, sexual and economic abuse perpetrated by any person to the other person

\footnotetext{
9 'Dictionary Meaning of Violence' <http://dictionary.reference.com/browse/violence> accessed 23 December 2012.

$10 \quad$ Bryan A. Garner, Black's Law Dictionary (West Publishing Co 1997) 1564.

11 UNICEF, 'Domestic Violence against Women and Girls'(2002) 6 Innocenti Digest, 2.
} 
with whom he has a family relationship'. It has included physical, mental, sexual and economic torture inflicted by one person against other person having familial relationship. Any other acts of abuse and emotional abuse are also covered in the definition. Therefore, domestic violence is all about violence inflicted to the person who falls within the relationships. Basically domestic violence is inflicted due to various reasons such as unequal power sharing, desire of son, consumption of alcohol, demand of dowry, inter caste marriage, poor economic condition of husband, poor economic condition of wife and many more.

\section{Analysis of Domestic Violence (Offence and Punishment) Act, 2009}

Legislation with regard to domestic violence is a modern trend. There is an increasing belief that special laws should be drafted, having special remedies and procedures. The first problem that arises with regard to legislation is that it allows for prosecution of men who beat their spouses even if the latter, under pressure, want to withdraw their claims. In response some countries have instructed police and prosecutors to proceed with cases even in situations where women indicated that they would rather not proceed. ${ }^{12}$ In the past, human rights protection was interpreted narrowly. The State's disability to prevent and punish violations was not viewed as a failure in its duty to protect human rights. The development of concept of state responsibility has now recognized that states also have an obligation to take preventive and punitive steps where rights are violated by private actors.

In 1992, the Committee on the Elimination of Discrimination Against Women (CEDAW) adopted General Recommendation 19, in which it confirmed that violence against women constitutes a violation of human rights and emphasizes that 'states may also be responsible for private acts if they fail to act with due diligence to prevent violations of rights or to investigate and punish acts of violence, and for providing compensation'. ${ }^{3}$ The concept of due diligence has been taken forward by the judgment of the Inter American Court of Human Rights in the case of Velázquez Rodriguez. The Court required the government to 'take reasonable steps to prevent human rights violations and to use the means at its disposal to carry out a serious investigation of violations committed within this jurisdiction, to identify those responsible, to impose the appropriate punishment and to ensure the victim adequate compensation'. ${ }^{14}$ Thus, the existence of a legal system criminalizing and providing sanctions for domestic assault would not in itself be sufficient; the government would have to perform its functions to 'effectively ensure' that incidents of family violence are actually investigated and punished. ${ }^{15}$

\footnotetext{
12 Radhika Coomaraswamy, Special Rapporteur on Violence against Women, Combating Domestic Violence <http://www1.umn.edu/humanrts/commission/thematic52/53-wom.htm> accessed 29 April 2013.

13 Committee on the Elimination of Violence Against Women, Eleventh Session, General Recommendation 19 GOAR 47 Session Supplement No. 38, UN Doc A/47/38.

14 Veláquez Rodríguez Case (Honduras), C(4) Inter American Court of Human Rights (1988) para 174.

$15 \quad$ Ibid para 167.
} 
In 1996, the United Nations Special Rapporteur on violence against women, its causes and consequences, presented a framework for model legislation on Domestic violence. ${ }^{16}$ The framework urges States to adopt legislation which, inter alia:

- Contains the broadest possible definition of acts of domestic violence and relationships within which domestic violence occurs;

- Includes complaints mechanisms and duties of police officers, including that the police must respond to every request for assistance and protection in cases of domestic violence and explain to the victims their legal rights;

- $\quad$ Provides for ex parte restraining orders and protection orders;

- Addresses both criminal and civil proceedings; and

- Provides for support services for victims, programs for perpetrators and training for police and judicial officials.

Nepal, though has guaranteed women's right as fundamental right in the constitution itself, has some discriminatory legal provisions against women. These discriminatory legal provisions are in the process of being revised in order to comply with CEDAW and other international commitments. ${ }^{17}$ Article 20(3) of the Interim Constitution has guaranteed that no physical, mental or other form of violence shall be inflicted upon any woman; it has also stated that such an act is punishable by law. The government of Nepal has formed the Domestic Violence (Offence and Punishment) Act 2009 in light of article 20(3) of the constitution. Further, Domestic Violence (Offence and Punishment) Rules 2010 has also been formulated. Domestic Violence (Offence and Punishment) Control Act 2009 is one of the major significant laws to uphold the constitutionally guaranteed women's rights which show that government of Nepal is committed towards the implication of the International Human Rights through national legislation.

The Preamble of the Act itself clarifies the reason behind its enactment which includes respect of the right of every person to live in a secure and dignified life; prevention and controlling violence occurring within the family as well as matters connected therewith and incidental thereto making such violence punishable for providing protection to the victim of the violence. Looking straight forward, it can be said that the Act is gender neutral and has no special significance to women. At the same time, the real existing scenario of Nepal reflects that women are being most victimized and highly vulnerable to the issues of

16 Report of the Special Rapporteur on violence against women, its causes and consequences (1996), A Framework on Model Legislation E/CN.4/1996/53/Add.2; See also UN Special Rapporteur on Violence against Women, Fifteen Years of the United Nations Special Rapporteur on Violence against Women (2009)

http://www2.ohchr.org/english/issues/women/rapporteur/docs/15YearReviewofVAWMandate.pdf> accessed 29 April 2013.

17 'United Periodic Report Nepal' (2010) <http//www.nhrcnepal.org/publication/doc/reports/UPR_Report2010.pdf> accessed 5 December 2012. 
domestic violence. The following significance can be analyzed within the Act that has provided protection measures for the human rights violation as a result of domestic violence. Additionally, some special measures have been taken giving attention to the situation that violence against women (VAW) takes place mostly within the periphery of the home itself. ${ }^{18}$ Since, the Act itself is gender neutral, the significances can equally be implied to the protection of women's human rights.

\section{Features of the Act}

The Objective ${ }^{19}$ of the Act is to respect the right of every person to live in a secure and dignified life as well as to prevent and control violence. It has also mentioned in its objective to control the violence that occurs within the family and for the matters connected with it. The Act assures to punish the offender and provide security to the victim. The Act for the first time explained domestic violence in a very comprehensive way, as an offence punishable by the Act itself. It is comprehensive in a sense that it defines the offence of domestic violence as including any form of physical ${ }^{20}$, mental $^{21}$, sexual ${ }^{22}$ and economic ${ }^{23}$ harm, also the acts causing reprimand or emotional harm caused by a person with whom s/he has a family relationship. For this purpose, the Act has incorporated the scope of an offence as committing, aiding or abetting or inciting for the commission of the act of domestic violence. ${ }^{24}$ This definition seems to be consistence with the definition as provided in Article 1 of CEDAW which mentions domestic violence as being a kind of discrimination, also along with comment $6^{25}$ of General Comment No 19. However, deprivation of the liberty has not yet been accounted for.

18 The report prepared by Nepal Police Women and Children Service Centre shows that around 6,000 complaints were filed in Domestic Violence within the period of FY 2055/56 to 2063/64 in which victims were women and asked for justice. The Annapurna Post (Nepal 2 August 2008). Domestic Violence (Offence and Punishment) Act 2009, preamble.

20 'Physical Harm means an act of committing or causing bodily harm or injury, holding as captive, inflicting physical pain or any other act connected therewith and incidental there to except the act of breaking the limbs of the body.

21 Mental harm means any act of threatening the victim of physical torture, showing terror reprimanding him/her, accusing him/her of false blame, forcefully evicting him/her from the house or otherwise causing injury or harm to the victim emotionally and this expression also includes any discrimination carried out on the basis of thought, religion or culture and customs and traditions.

22 Sexual harm means sexual misbehavior, humiliation, discouragement, or harm in self respect of any person; or any other act that hampers safe sexual health

23 Economic harm' means deprivation from using jointly or privately owned property or deprivation of or access to employment opportunities, economic resources or means.

24 Domestic Violence (Offence and Punishment) Act 2009 s 3.

25 The Convention in Article 1 defines discrimination against women. The definition of discrimination includes gender-based violence, that is, violence that is directed against a woman because she is a woman or that affects women disproportionately. It includes acts that inflict physical, mental or sexual harm or suffering, threats of such acts, coercion and other deprivations of liberty. Genderbased violence may breach specific provisions of the Convention, regardless of whether those provisions expressly mention violence. 
In the Act, the provision regarding the locus standi seems to be liberal since any person who has the reason to believe that an act of domestic violence has been, or is being, or is likely to be committed, may immediately lodge a written or oral complaint with the Police Office, National Women's Commission or Local body. And, also the victim of an act of domestic violence can directly enter in to court to file the case. ${ }^{26}$ The Act providing the jurisdiction to the National Women's Commission (NWC) seems to have given special attention to the women's access to justice which can be advocated as the special measure taken for the compliance to CEDAW. The Act has clearly stated that in case of complaint filed before the NWC that necessary actions shall be taken as per the prevailing laws of NWC. ${ }^{27}$

Another praiseworthy feature of the Act is the provision of immediate protection of the victim till final decision of the case. ${ }^{28}$ The Act has made the alternative means of protecting the victim in case the perpetrator is unable to pay treatment expenses because of some economic reason. It is to be provided by the Service Centers established for the immediate protection of the victim itself by the Government in pursuance to the Section 11 of the Act. In addition to this, the Service Centers are entitled to provide separate accommodation to the victim during their treatment and also legal aid, psycho-consultant service, psychological service along with economic aid as per the necessity of the victim. The Act also includes the provision of punishment to a person who denies doing an act for immediate protection of the victim as per the court's order.

The Act has also provided for the alternative means of dispute settlement, that is, through the means of reconciliation ${ }^{29}$ which seems significant in the disputes relating to family matters. The Act has provided that Police Office or local body upon receiving the complaint of their jurisdiction should find reasons to believe that an act of domestic violence has been occurred and if the victim desires, Police may conduct the reconciliation between the parties within 30 days from the date of registration of such complaint. However, the Act has not prescribed that NWC and court can conduct reconciliation in the case.

The Act has provided that the cases relating to the Domestic Violence under this Act must be heard in close camera proceeding and hearing if requested by the victim. ${ }^{30}$ The very concept of the Act has guaranteed the right to privacy of an individual which ultimately respect the dignity of human life.

As per the Act, cases filed for the offence of domestic violence have to proceed as per the Summary Procedure Act, 2028(1971). ${ }^{31}$ This means, the case filed under this Act has to be decided within 90 days from the date of the statement made by the respondent. This

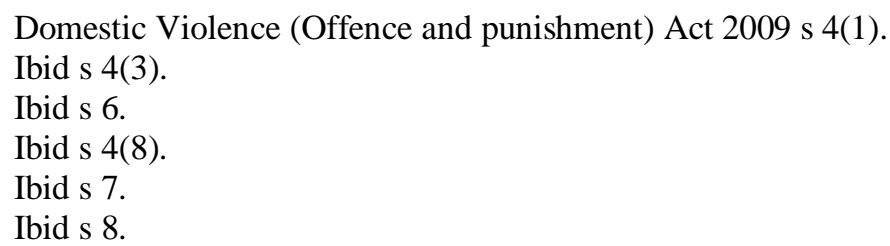


provision has made prompt access to justice even in the case if it fails in the process of reconciliation.

The Act has made the provision regarding the compensation for the victim of the domestic violence which can be provided by the perpetrator in the issuance of the court order where the basis for compensation is the nature of an act of domestic violence and degree, the pain suffered by the victim and the economic and social status of the victim ${ }^{32}$. The Act seems to have made an effort to make the law remedial in case of victim of domestic violence. It is very commendable that the Act has provided the limitation of ninety days to file a case. ${ }^{33}$

The Act has incorporated the provision of additional punishment in following two situations, double punishment upon every repetition of the crime ${ }^{34}$ and an additional $10 \%$ punishment if the offender happens to be in the public post. ${ }^{35}$ The concept of punishment with the provisions of aforesaid additional punishment seems to be oriented to discourage the offence of domestic violence from being repeated. In addition to this, the concept also adds more responsibility on the public post holders not to commit such violence thereby reinforcing a mechanism for holding the government responsible for human rights protection.

\section{Lacunae of Domestic Violence (Offence and Punishment) Act 2009}

Comprehensive legislation is fundamental for an effective and co-ordinated response on violence against women. Domestic Violence (Offence and Punishment) Act, 2009 is the landmark step to Nepal government to control violence against women. This truth cannot be denied. This Act has been formulated following the principle of due diligence to prevent the violation of rights, for investigation and punishment of acts along with compensation for victims. But it is not free from flaws yet. The Act contains several lacunae, some of which are as follows:

a. The act defines domestic violence as any form of physical, mental, sexual and economic harm perpetrated by a person to a person with whom he/she has a family relationship which also includes any acts of reprimand or emotional harm. ${ }^{36}$ Furthermore, it defines domestic relation as a relationship between two or more persons who are living together in a shared household and are related by decent, marriage, adoption or are family members living together as a joint family or a dependent domestic help living in the same family.

b. However, the UN Model Legislation on Domestic Violence provides for two types of relationship falling under the scope of domestic violence. They are violence against women in the family and within interpersonal relationship like living relationship, roommates, boyfriend-girlfriend relationship. Hence, Domestic Violence (Offence

Ibid s 10 .

Ibid s 14.

Ibid s 13(3).

Ibid s 13(4).

Ibid s 2(a). 
and Punishment) Act, 2009 lacks to bring interpersonal relationship within the scope of domestic violence.

c. This Act also lacks to cover violence against women occurring in the name of cultural practice.

d. Section 4(1) provides that complaint can be filed in the Police Office, National Women Commission or local bodies and directly at the Court as well ${ }^{37}$. Providing responsibility to three institutions can make all them irresponsible and unaccountable.

e. Section 4 (4) on filing of complaint or petition states that if the complaint is lodged in the Police Station, excluding the time of travel, the perpetrator shall be produced in the Police Office within 24 hours of the lodging of the complaint for the recording of his statement and if he disobeys to be brought, force may be applied for his arrest. Section 4(5) similarly allows for application of force for the arrest of the perpetrator for the purpose of being produced before the local bodies where a complaint may have been filed. None of the provisions however allow for the detention of the perpetrator either in police or judicial custody until a settlement is reached, or an interim order is issued by the court. This lacuna threatens the very basis of access to justice for women who may further be vulnerable to violence upon having lodged a complaint and even to return back to the home of the perpetrator.

f. Section 4 (6) provides for sending the victim to the nearest hospital or health post for necessary check-up and an injury report to be drawn up. But it is not clear about who should take the victim to the hospital, who should bear the medical expenses and alternative in case the nearest hospital or health post cannot provide for the service. The Domestic Violence (Offence and Punishment) Rules, 2067 is silent on this aspect.

g. Section 4(8) provides for conducting reconciliation within 30 days from the date of registration of complaint. Reconciliation is appropriate for the victim being forced to reconcile and frequently resulting in the victims being forced to return home to their abusive spouse. It would have been further better that if the Act has made the provision regarding the family court for the settlement of such cases relating to domestic violence since it is completely a family matter within which the provision of the reconciliation can be kept. And, also the Act is a failure in the aspect that there is no mechanism that could observe whether the conciliation has actually been executed. Section 4(9) provides for the assistance of psychologist, sociologist, social activist and a family member during the reconciliation. But the Act lacks to define that a person having what qualifications can be termed as psychologist, sociologist and social activist.

h. Section 5 states that Court shall take action: a) upon the receipt of a complaint as per Subsection (11) of Section 4, the Court shall prosecute and decide the case as per this Act, on

$37 \quad$ Ibid s 5. 
the basis of such complaint; b) Notwithstanding anything contained in sub-section (1), the aggrieved person may directly file his complaint with the Court. However the law contains no additional provision for the facilitation of filing a direct complaint with the court or the procedure to be followed in evidence collection, and prosecution of the perpetrator. In the absence of any existing legal provision, rule or guideline for the same, women shall continue to be unable to have direct access to the court thereby defeating the very purpose of providing protection from domestic violence.

i. Under section 6, interim protection order may be granted, if the Court has reason to believe, on the basis of preliminary investigation of the complaint that the victim needs to be given immediate protection. It might be granted till the time the final decision on the complaint is made. But the Act nowhere mentions about the responsible authority for preliminary investigation, moreover it also does not provide when to start preliminary investigation, before or after the file is taken to Court from the police or local bodies.

j. As per Section 7 the proceedings is to be held in camera only if requested by the victim. But it should to be made compulsory as incase victim may not know about this provision.

k. UN Model legislation provides for establishment of Special family courts and the judiciary to be provided with intensive and specialized training to handle more complex cases. But the Act of Nepal lacks this aspect.

1. The Act lacks counseling programs for perpetrators unlike UN model legislation. Counseling programs must be designed to help the perpetrator take responsibility for his violence and make a commitment not to inflict further violence, educating the perpetrator on the illegality of violence.

m. UN Model legislation offers for trainings to be provided for the police officials regarding domestic violence like its nature, extent, causes and consequences, the legal rights and remedies available to its victims, the services and facilities for victims and abusers. Further the legal duties imposed on police officers to make arrests, to offer protection and assistance along with techniques for handling incidents of domestic violence promoting the safety of the victim and her dependents. But the Act of Nepal does not mention anything about providing trainings to the police.

n. The Act provides legal provision on remedial basis only. It lacks to include preventive measures.

o. The punishment in section 13 is insufficient. Domestic violence is really harmful and its effects can also be much harsher. So the fine ranging from NRs 3000 to NRs 25000 and imprisonment of month or both, is not proportional to the severity of the crime. 


\section{Conclusion}

Any kind of abusive behavior is violence. When such abusive behavior is done against women, it is violence against women. And when violence against women happens within domestic relationships, it is domestic violence. Domestic violence can be devastating for the physical, mental, social and economic wellbeing of women. Hence, international community through various instruments has pursued securing women from the violence both in public and private life. Upholding the principle of due diligence, states formulate domestic laws to control domestic violence and ensure safety of women within domestic relationships. Nepal has formulated Domestic Violence (Offence and Punishment) Act 2009 inspired by the principle of due diligence and seeks to implement the right of women guaranteed in the Interim constitution of Nepal 2007. The Act tries to ensure women's security against domestic violence as it aims to curb domestic violence in Nepal. It encompasses principles of UN Model Legislation such as criminalization of the domestic violence, complaint mechanisms, protection orders for the victim, investigation of crime, and support to the victim. But the Act itself is not enough for addressing the domestic violence in Nepal. It has several lacunas that are to be rectified. It lacks various issues suggested by the UN Model legislation such as broadening the definition of domestic violence, confusion in the complaint mechanism, rehabilitation for the victim, counseling of the offenders in minor issues, training to the police officials and judicial officers, establishment of a special court etc.

Moreover, the implementation of this Act is also not clear. The Act fails to provide adequate procedures for the investigation and adjudication of the case. The reconciliation provision can be used to force the victim to reconcile and further face more violence repeatedly. The Act also fails to address many issues without which its implementation is very difficult. Many of its provisions themselves act as hurdle. In Spain, reconciliation is not allowed in cases of domestic violence. But in Nepal, reconciliation becomes a compulsion to the victim because of social structure. Hence the provision of reconciliation can be a disadvantage to victim. Moreover the punishment for the offender is nominal, which implies that there is less fear of the punishment in the society. As the penalty ranges within NRs 3000 to NRs 25000 and imprisonment is upto 6 months, there is a high chance of people committing crime more often and getting away with it simply by paying the nominal fine. Hence, Domestic Violence (Offence and Punishment) Act 2009 is not adequate to address the problem of domestic violence in Nepal as it has several lacunas as regards its execution, which are to be corrected. The following recommendations are suggested by the researcher based on the study:

a. Define domestic violence in a broader term as suggested by UN model legislation. It has to cover violence against women in both family and interpersonal relationship.

b. Amend the provisions of Domestic Violence (Offence and Punishment) Act 2009 in consonance with UN Model Legislation. 
c. Introduce a preventive approach to the Domestic Violence (Offence and Punishment) Act as well.

d. Increase the punishment for the offences of domestic violence.

e. Develop an implementation mechanism for the enforcement of provisions of Domestic Violence (Offence and Punishment) Act 2009.

f. Conduct awareness campaigns to make people known about the presence of Domestic Violence (Offence and Punishment) Act 2009.

g. Introduce Domestic Violence (Offence and Punishment) Act 2009 in educational curricula.

h. Establish fast track court to handle with cases of domestic violence and ensure speedy justice.

$* * * * * * * * * * * * * * * * * * *$ 